\title{
Invited review: Determinants of farmers' adoption of management-based strategies for infectious disease prevention and control
}

\author{
Caroline Ritter, ${ }^{* 1}$ Jolanda Jansen,† Steven Roche,‡ David F. Kelton, $\ddagger$ Cindy L. Adams,§ Karin Orsel, ${ }^{*}$ \\ Ron J. Erskine,\# Geart Benedictus,II Theo J. G. M. Lam, I and Herman W. Barkema* \\ *Department of Production Animal Health, Faculty of Veterinary Medicine, University of Calgary, 2500 University Dr., Calgary, AB, \\ T2N 1N4, Canada \\ †St. Anna Advies, 6525 ZM Nijmegen, the Netherlands \\ ‡Department of Population Medicine, University of Guelph, 50 Stone Rd., Guelph, ON, N1G 2W1, Canada \\ $\S$ Department of Veterinary Clinical and Diagnostic Sciences, Faculty of Veterinary Medicine, University of Calgary, 2500 University Dr., \\ Calgary, AB, T2N 1N4, Canada \\ \#Department of Large Animal Clinical Sciences, Michigan State University, East Lansing 48824 \\ IBenedictus Advies, 8501 NC Joure, the Netherlands \\ IDepartment of Farm Animal Health, Faculty of Veterinary Medicine, Utrecht University, Yalelaan 7, 3584 CL Utrecht, the Netherlands
}

\begin{abstract}
The prevention and control of endemic pathogens within and between farms often depends on the adoption of best management practices. However, farmers regularly do not adopt recommended measures or do not enroll in voluntary disease control programs. This indicates that a more comprehensive understanding of the influences and extension tools that affect farmers' management decisions is necessary. Based on a review of relevant published literature, we developed recommendations to support policy-makers, industry representatives, researchers, veterinarians, and other stakeholders when motivating farmers to adopt best management practices, and to facilitate the development and implementation of voluntary prevention and control programs for livestock diseases. Farmers will make management decisions based on their unique circumstances, agricultural contexts, beliefs, and goals. Providing them with rational but universal arguments might not always be sufficient to motivate on-farm change. Implementation of recommended management practices is more likely if farmers acknowledge the existence of a problem and their responsibility to take action. The perceived feasibility and effectiveness of the recommended management strategy and sufficient technical knowledge further increase the likelihood of adequate adoption. Farmers will also weigh the expected advantages of a proposed change against the expected disadvantages, and these considerations often include internal drivers such as pride or the desire to conform
\end{abstract}

Received September 8, 2016.

Accepted January 3, 2017.

${ }^{1}$ Corresponding author: cmnritte@ucalgary.ca with perceived standards. Extension tools and farmers' social referents (e.g., veterinarians, peers) not only provide technical information but also influence these standards. Whereas mass media have the potential to deliver information to a broad audience, more personal approaches such as participatory group learning or individual communication with farm advisors can enable the tailoring of recommendations to farmers' situations. Approaches that appeal to farmers' internal motivators or that unconsciously elicit the desired behavior will increase the success of the intervention. Collaboration among stakeholders, assisted by social scientists and communication specialists, is necessary to provide a context that facilitates on-farm change and transfers consistent messages across extension tools in the most effective way.

Key words: prevention and control program, farmer compliance, motivation, communication, behavior change

\section{INTRODUCTION}

Livestock farmers worldwide face endemic disease challenges that threaten animal health and welfare. These diseases can have a substantial economic impact on individual enterprises and on the farming industry as a whole (Wierup, 2012). Therefore, although the relevance of specific diseases might vary by country, the prevention and eradication of infectious animal diseases [i.e., diseases that can be spread directly or indirectly between animals (and potentially to humans)] has become an increasing focus for many nations. Despite huge advances in the development of livestock vaccines and treatment options, the implementation of best management practices is still the most effective way to prevent and control many infectious diseases on farms. Farmers are encouraged to implement specific strate- 
gies to mitigate the risk of disease transmission, not only for the sake of their animals' health and welfare, but also to protect humans from zoonotic pathogens (OIE Animal Production Food Safety Working Group, 2006). However, poor on-farm adoption of recommendations to enhance general biosecurity practices, or of strategies to decrease transmission of specific diseases, is common (Bell et al., 2009; Brennan and Christley, 2013; Sayers et al., 2013). Furthermore, participation rates in voluntary disease prevention and control programs are often below 30\% (Hoe and Ruegg, 2006; Hop et al., 2011; Nielsen, 2011). These experiences suggest that the methods used to motivate participation in control programs and adoption of recommended practices have been suboptimal.

Agricultural extension refers to activities and communication channels that facilitate changes in farmer knowledge, attitudes, and behavior by synthesizing, exchanging, and applying information (Black, 2000; Anderson and Feder, 2004). Although agricultural extension differs depending on the context, traditional "top-down" tools such as newsletters or magazines are often the primary routes of knowledge transfer, and they assume that farmers make decisions based purely on scientific rationale (Roche, 2014). However, it is widely accepted that farmers' decision-making varies, influenced by factors that are not solely based on policy, economic considerations, or rational judgment (Edwards-Jones, 2006; Noordhuizen et al., 2008b). Some variability can be explained by individual farmer traits (e.g., personality, attitudes, beliefs, intentions, values, skills, and knowledge). Remarkably, these socio-psychological variables often explain more variation in farm performance than farmers' measurable management practices (Bigras-Poulin et al., 1985; van den Borne et al., 2014). To account for these factors, different theoretical frameworks have been applied in the agricultural context. Two of the frameworks most commonly used to investigate the effects of sociopsychological variables on farmers' decision-making and better understand farmer behavior, are the Health Belief Model (Janz and Becker, 1984) and the Theory of Planned Behavior (Ajzen, 1991).

In addition to socio-psychological factors, external influences such as input from social referents (e.g., herd veterinarians, colleagues, or family) and agricultural extension conduits (e.g., printed media or discussion groups) can also affect farmers' management decisions (Ritter et al., 2015; Roche et al., 2015).

The objective of this narrative review was to describe the available information on (1) the factors that contribute to farmers' adoption of recommended management strategies; and (2) the influence of social referents and extension tools on farmers' management decisions.
Our focus was farmer behavior related to improving animal health, but where applicable, we have included a selection of findings on animal welfare to add relevant information from other contexts. Furthermore, the scope of this review was voluntary management-based prevention and control of endemic infectious livestock diseases (i.e., farmers' decision-making in the absence of compulsive regulations) on commercial farms in economically developed countries. To meet the second objective, we discussed the main communication channels used to provide information and support farmers in adopting recommended management practices.

Based on the evidence as it pertains to the delineated scope, we provide recommendations to policy-makers, industry representatives, researchers, veterinarians, and other stakeholders to facilitate the adoption of on-farm management practices and assist in the development and implementation of voluntary control programs for endemic infectious livestock diseases.

\section{SOCIO-PSYCHOLOGICAL INFLUENCES}

Every farmer has their own unique combination of demographic factors (e.g., age, sex, education), personality, previous experiences, routines, and goals, as well as economic, cultural, and family influences (Wilson et al., 2015; Frössling and Nöremark, 2016). These individual characteristics contribute to farmers' views about animal health, prevention and control strategies, and influence their decision-making (Figure 1). Not every management decision a farmer makes might appear logical from an outside perspective (Kristensen and Jakobsen, 2011a). An understanding of a farmer's mindset and the specific factors that combine to influence that mindset is crucial for motivating them to change. The socio-psychological influences on farmers' adoption of recommended management practices described in the first part of the review were considered the most relevant and were often derived from constructs described in the Health Belief Model or the Theory of Planned Behavior (Figure 1). It is particularly important to consider these factors when formulating voluntary prevention and control programs, and we have provided related recommendations (Tables 1 to 4). However, interventions to change farmer behavior must acknowledge that farmers are not a homogeneous group and cannot be convinced by relying only on educational arguments (Jansen et al., 2010b,c). Furthermore, farmers' context (e.g., laws and regulations, market prices, or quality programs) can affect decision-making by inhibiting or facilitating the recommended management changes. Because of the influence of farmers' internal logic and context on their decision-making, it is impossible to provide a "one-sizefits-all" solution (Kristensen and Jakobsen, 2011a). 
Problem Awareness and Perception of Responsibility

Problem Awareness. People are less willing to change their behavior if they deny the negative (future) effects of their current habits or of their current situation (e.g., the negative effects of smoking or obesity on health; Orji et al., 2012; Mantler, 2013). In this way, informing farmers about the presence of a pathogen or disease on their farm is an important step, but it does not guarantee that they will regard it as an important issue (Leach et al., 2010a; Ritter et al., 2016; Table 1). For example, Texas beef and Canadian dairy producers with Johne's disease in their herd often did not consider it a problem (Benjamin et al., 2010; Sorge et al., 2010a), and 90\% of dairy farmers in England and

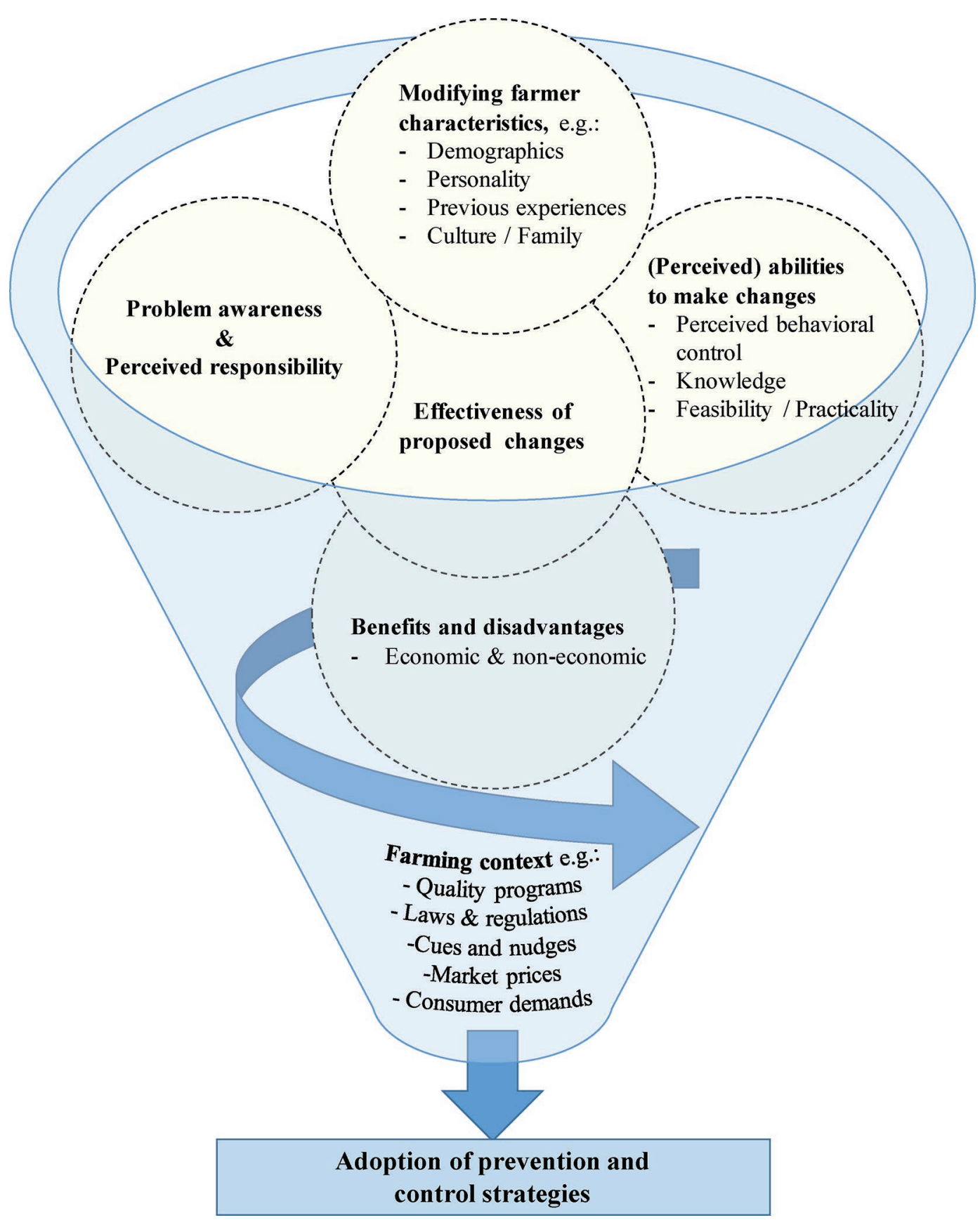

Figure 1. Socio-psychological factors that influence the adoption of on-farm management strategies for improved infectious disease prevention and control. Color version available online. 
Table 1. Recommendations to enhance farmers' problem awareness and sense of responsibility

\begin{tabular}{ll}
\hline Recommendation & Reference \\
\hline - Confirm and communicate the importance of the disease to farmers. & Lam et al., 2013 \\
- Provide guidelines for what is considered "normal" or the targeted goal (consider using case studies/stories & Kleen et al., 2011; \\
to convey "normal") to alter farmers' frame of reference. Use benchmark tools to compare individual farm & Barkema et al., 2013 \\
performances against a standard or other farmers' performances. & Wassink et al., 2005 \\
- Inform farmers that even if they do not see disease, they still may have subclinically infected (infectious) & \\
$\begin{array}{l}\text { animals that could cause substantial losses. } \\
\text { - If diagnostic tests lack sensitivity, tell farmers that the issue might be bigger than the results suggest and, if }\end{array}$ & Wolf et al., 2014 \\
possible, provide estimates of the true incidence, prevalence, or both. & Lam et al., 2013 \\
- Inform farmers that the introduction of disease increases without proper preventive measures and is possible & Heffernan et al., 2008 \\
- Clarify and justify farmers' responsibilities for disease control while encouraging them to take on this & \\
\hline
\end{tabular}

Wales did not see lameness as a problem, despite an average prevalence of $36 \%$ (Leach et al., 2010a). To change their management practices, farmers need to believe that their current situation poses a problem or increases their risk of future problems, a notion that is described as "perceived threat" in the Health Belief Model (Janz and Becker, 1984; Casal et al., 2007; Benjamin et al., 2010). For example, concern about production losses due to Johne's disease was a main reason why dairy farmers participated in a voluntary Johne's disease control program (Nielsen, 2011).

Farmers also differ in their perception of the threshold at which an issue becomes a problem for their operation (Jansen et al., 2010d; Jansen and Lam, 2012). This so-called "frame of reference" is often influenced by farmers' descriptive norms (e.g., their perception of how other farmers deal with the issue), injunctive norms (i.e., their perception of what is approved by other people), comfort rates, and experiences (Lam et al., 2007; Noordhuizen et al., 2008a; Jansen et al., 2016; Table 1). Examples of the influence of farmers' frame of reference include its association with their willingness to decrease mastitis rates, or with variations in mastitis incidence and bulk-milk SCC (Jansen et al., 2009; Jansen and Lam, 2012; Schewe et al., 2015).

A lack of diagnostic test sensitivity or of obvious clinical signs might cause a farmer to overlook an existing problem (Leach et al., 2010a; Wolf et al., 2014). Without necessarily knowing the herd's test status for Mycobacterium avium ssp. paratuberculosis (MAP), almost $80 \%$ of the farmers who thought they had observed clinical cases in their herd considered Johne's disease to be a serious problem, whereas only $10 \%$ of farmers who had not observed clinical cases shared that perception (Norton et al., 2009). Therefore, it is more challenging to motivate control strategies for diseases that spread silently or that lack sensitive diagnostic tests (Wassink et al., 2005; Benjamin et al., 2010; Table 1 ), particularly because farmers evaluate any problem not only on an "absolute" scale but also in relation to other issues that demand their attention (Leach et al., 2010a). Ultimately, farmers will spend their resources (e.g., time, money, space) on the issues they think are most urgent, will have the most severe negative impact, and are solvable (Rodrigues and Ruegg, 2005; Elliott et al., 2011; Bruijnis et al., 2013, Horseman et al., 2014). For example, dairy farmers who perceived that they had difficulty finding time to complete all tasks on the farm often gave higher priority to milking cows, limiting the care of calves (e.g., providing colostrum as soon as possible after birth; Santman-Berends et al., 2014).

Reports of estimated negative economic impact are available for the most important diseases that affect cattle (e.g., mastitis, bovine leukosis, bovine viral diarrhea, Johne's disease; Tiwari et al., 2007; Hogeveen et al., 2011). However, it is uncertain whether farmers are aware of these publications. Furthermore, lack of agreement in published estimates might cause confusion among farmers or doubt about the reports' credibility. Nevertheless, even when estimates of production losses based on bulk-milk SCC were presented to farmers, success in motivating management change was limited when no further incentives were offered (van Asseldonk et al., 2010; Lam et al., 2010).

Farmers who do not have a particular disease on their farm evaluate its threat to their enterprise based on perceived susceptibility (i.e., how likely are animal health problems to occur; Janz and Becker, 1984). The current local disease status appears to play an important role in farmers' perceptions of susceptibility (Table 1), although each farmer likely has a different threshold at which they perceive the geographic proximity of disease 
occurrences to be a threat to their farm. In that sense, farmers are more inclined to take additional precautions if they perceive the risk of pathogen introduction onto their farm to be high: for example, if transmission risks are elevated because of disease occurrences in the area (Ekboir, 1999; Garforth et al., 2013; Toma et al., 2013; Toma et al., 2015).

Perception of Responsibility. To take action, farmers need to believe that they are responsible for implementing the management strategies being advocated (Blackstock et al., 2007; Wauters and Rojo Gimeno, 2014; Table 1). For example, cattle farmers' perception of responsibility for Escherichia coli 0157 control was positively associated with their willingness to spend time or money on this issue (Toma et al., 2015). For the majority of farmers enrolled in voluntary Johne's disease programs, concerns about consumer health or consumer perceptions of a link to Crohn's disease were key factors for participation (Sorge et al., 2010a; Nielsen, 2011). Other studies, however, have revealed that farmers' considerations of their own farm's performance were often more important to them than responsibility for consumer health or awareness of the industry sector (Kovich et al., 2006; Hop et al., 2011; Ritter et al., 2015). This notion was supported by Jones et al. (2015), who reported that farmers' primary reason for reducing antibiotic use was not concern about resistance in cows and humans, but an attempt to decrease medicine costs. Similarly, helping the dairy sector as a whole to meet its goals was not a strong incentive for farmers to improve mastitis management (Valeeva et al., 2007).

Farmers often mention that government, food retailers, or auxiliary industries need to assume more responsibility for biosecurity (Gunn et al., 2008; Garforth et al., 2013). For example, $44 \%$ of cattle farmers from England and Wales stated that the government should contribute financially to controlling zoonotic diseases (Ellis-Iversen et al., 2010; Table 1), and 33\% of cattle farmers in the United Kingdom felt that control of $E$. coli O157 should be the government's responsibility, at least in part (Toma et al., 2015). In contrast, the reluctance of cattle and sheep farmers to take responsibility for biosecurity in the United Kingom did not revolve around the government, but was instead due to a lack of trust within the farming community (Heffernan et al., 2008). In that regard, farmers' investment in preventive measures is most effective if others are doing the same. Farmers may be more inclined to assume responsibility as part of a joint effort rather than herd by herd (Hovi et al., 2005; Lindberg et al., 2006; Gunn et al., 2008; Heffernan et al., 2008; Brennan and Christley, 2013; Table 1).

\section{Effectiveness of Recommended Strategies}

Even farmers who recognize the importance of disease prevention and control and feel responsible for taking action may be reluctant to make on-farm changes if they do not believe that the proposed strategies are effective in preventing pathogen introduction, reducing pathogen prevalence, or mitigating clinical cases (Janz and Becker, 1984; Jansen et al., 2010b; Roche, 2014; Ritter et al., 2016; Table 2). Unfortunately, farmers are often uncertain about the effectiveness of recommended measures, or express doubt about the efficacy of a control program (Garforth et al., 2013; Alarcon et al., 2014). This perception is likely strengthened if farmers are not sufficiently informed about a strategy's success or if, due to the complex or chronic nature of some diseases, recommendations are based largely on epidemiological principles and biological plausibility rather than on evidence from clinical trials or field studies (Table 2). In particular, multifactorial chronic conditions that require a substantial amount of effortand for which immediate and accurate assessment of the effect of adopted management changes is limited or unavailable - might reinforce farmers' perceptions that management strategies are ineffective (Raizman et al., 2006; Jansen and Lam, 2012; Table 2).

Producers motivated to increase their management efforts were often frustrated or discouraged when they perceived available strategies to be ineffective (Ritter et al., 2016). Similarly, Australian cattle farmers believing they could succeed in temporarily eradicating cattle ticks from their farm considered re-infestation from neighboring properties to be a major limiting factor (Jonsson and Matschoss, 1998). Free-range poultry producers regarded biosecurity measures directed at reducing disease transmission between buildings to be futile and a "waste of time" (Garforth, 2011), instead focusing on practices they perceived to be more worthwhile, such as separating new animals on arrival or cleaning buildings between batches.

For swine farmers, effectiveness was the strongest driver in adopting recommended disease prevention and control measures for endemic and epidemic diseases (Valeeva et al., 2011). Positive perceptions of the effectiveness of proposed measures to control mastitis was not only linked to dairy farmers' adoption intent, but also strongly associated with mastitis incidence (Jansen et al., 2009). Similarly, the reason most commonly given by farmers for the adoption of a digital dermatitis protocol in cattle was its perceived effectiveness (Relun et al., 2013). However, the diversity of prevention and treatment protocols for foot health likely enhances farmers' insecurity about best practices and emphasizes 
Table 2. Recommendations to enhance farmers' belief in the effectiveness of proposed strategies

\begin{tabular}{lc}
\hline Recommendation & Reference \\
\hline - Promote solid, evidence-based management recommendations, taking the most current knowledge into & Brightling et al., 2009 \\
account, and provide information about the effectiveness of various strategies, customized for each farm. & \\
- If reports are available, inform farmers on the success of implemented management strategies and & Ritter et al., 2015 \\
comparable prevention and control programs. & Lam et al., 2013 \\
- Prepare farmers for the fact that it might take time to observe the positive effects of preventive measures, & Ivemeyer et al., 2015; \\
- Und set realistic goals for the decrease in disease incidence and prevalence. & Roche et al., 2015 \\
\hline
\end{tabular}

the need for standardized recommendations based on credible research (Solano et al., 2017; Table 2).

\section{Farmers' (Perceived) Ability to Implement Recommended Management Practices}

Perceived Behavioral Control. Farmers' positive belief in their ability to successfully implement a recommendation is a necessary step toward improved disease control (Ellis-Iversen et al., 2010). This belief in the ability to succeed is called "perceived behavioral control" in the Theory of Planned Behavior (Ajzen, 1991). A similar concept in the Health Belief Model is "self-efficacy" (Janz and Becker, 1984). Perceived behavioral control and self-efficacy are influenced by a person's belief that they have sufficient knowledge to accomplish the task, that they can overcome habitual behavior, and the perceived feasibility of the recommendation (Garforth, 2015; Frössling and Nöremark, 2016).

In human health research, health care workers felt disempowered to correct poor compliance with hygiene measures if they perceived a lack of organizational commitment from the hospital (Smiddy et al., 2015). Similarly, farmers are part of a larger context and can only alter their behavior if their context allows for change. Farmers need organizational and institutional support that facilitates recommended changes (e.g., financial lenders that support investment in biosecurity measures; Kristensen and Jakobsen, 2011b; Table 3).

The limited work in the veterinary environment suggests that positive perceived behavioral control does promote farmers' adoption of management strategies. For example, perceived behavioral control was positively associated with farmers' intention to improve dairy cow foot health (Bruijnis et al., 2013) or to improve sustainable practices in gastrointestinal nematode control with diagnostic methods (Vande Velde et al., 2015). Farmers' perceived self-efficacy appeared to be a key influence affecting mastitis control strategies on Dutch dairy farms (Jansen and Lam, 2012), and successfully solving previous mastitis outbreaks probably enhanced farmers' feeling of control. Similarly, calf managers' experience solving calf mortality problems appeared to strongly affect their belief in their ability to minimize mortality rates, and likely influenced whether

Table 3. Recommendations to enhance farmers' (perceived) ability to implement recommended changes

\begin{tabular}{|c|c|}
\hline Recommendation & Reference \\
\hline $\begin{array}{l}\text { - Create a context that facilitates on-farm changes (e.g., by supporting the implementation of biosecurity } \\
\text { measures financially). }\end{array}$ & Weber and Lam, 2012 \\
\hline $\begin{array}{l}\text { - Share stories of successfully implemented management changes or offer practical demonstrations of options } \\
\text { for management adoption to improve farmers' attitudes, intentions, and uptake of recommended measures. }\end{array}$ & $\begin{array}{l}\text { Ivemeyer et al., } 2015 \\
\text { Roche et al., } 2015\end{array}$ \\
\hline $\begin{array}{l}\text { - Disseminate sufficient information about the issue, proposed control strategies, and the control program, } \\
\text { including expected time and financial commitments, to avoid insecurities and misconceptions that prevent } \\
\text { enrollment. }\end{array}$ & Brightling et al., 2009 \\
\hline $\begin{array}{l}\text { - Give farmers customized recommendations for on-farm improvements that are feasible and practical for } \\
\text { their operation. }\end{array}$ & $\begin{array}{l}\text { Ritter et al., } 2015 \\
\text { Roche et al., } 2015 \\
\text { Toma et al., } 2015\end{array}$ \\
\hline $\begin{array}{l}\text { - Consider using structured risk assessments and management plans to facilitate discussion about perceived } \\
\text { constraints and break the complexities of targeted disease control into parts, which can be managed more } \\
\text { easily. }\end{array}$ & $\begin{array}{l}\text { Wilson et al., } 2015 \\
\text { Wolf et al., } 2015\end{array}$ \\
\hline
\end{tabular}


they were able to prevent a crisis from becoming permanent (Vaarst and Sørensen, 2009). Demonstrations of successfully implemented management strategies on producers' farms can positively influence farmers' attitudes and their belief in their ability to make a change (Roche et al., 2015; Table 3).

Studies in the human sector are abundant and suggest that perceived behavioral control and self-efficacy play important roles in patient adherence to medical treatment, physical activity or healthy nutrition (e.g., Fransen et al., 2009; Kreausukon et al., 2012; Parschau et al., 2013) for example, but these factors are not well studied in veterinary medicine, and more research is needed to form conclusions about their effect on farmers' management decisions.

Knowledge. To make effective changes farmers need to have sufficient knowledge about disease and management strategies to reduce transmission (Lam et al., 2007; Brightling et al., 2009; Ellis-Iversen et al., 2010; Racicot et al., 2012b; Table 3). Farmers' knowledge about Johne's disease and its control was positively associated with their attitudes about participating in a voluntary control program (Benjamin et al., 2010; Ritter et al., 2015; Table 2). Also, knowledge about dairy foot-health management likely enhanced farmers' intention to take action (Bruijnis et al., 2013), and the prevalence of lameness in dairy cows in England was negatively associated with farmers' awareness, knowledge, and level of training (Mill and Ward, 1994).

Some farmers believe that they have a good understanding of appropriate measures to optimize dairy cow foot health, mastitis incidence, or calf-rearing practices (Kuiper et al., 2005; Bruijnis et al., 2013; SantmanBerends et al., 2014). This perceived knowledge is often acquired from their experience as farmers and less from formal training (Garforth et al., 2013). However, veterinary practitioners did not always agree that farmers had sufficient knowledge to provide the best care for their animals (Santman-Berends et al., 2014). Farmers' lack of knowledge and understanding was the reason most frequently stated by cattle veterinarians for why their clients did not adopt many biosecurity measures (Pritchard et al., 2015).

Testing actual knowledge revealed that farmers were often unaware of the associated risks and transmission pathways to animals or humans of pathogens such as Staphylococcus aureus, Salmonella, E. coli, or bovine viral diarrhea virus (Kuiper et al., 2005; Young et al., 2010a; Lanyon et al., 2015; Toma et al., 2015). Benjamin et al. (2010) reported that $75 \%$ of beef cattle farmers who agreed that Johne's disease was a problem on their farm stated that they were unsure of how to prevent and control it (Table 3). Furthermore, dairy farmers who were familiar with Johne's disease applied management strategies that were similar to those applied by farmers who were unfamiliar with the disease (Wells and Wagner, 2000).

Farmers' reasons for not acquiring sufficient knowledge range from lack of time to uncertainty about which sources to consult for clear and relevant information (Hop et al., 2011; Alarcon et al., 2014; Lanyon et al., 2015). Farmers who have little experience with Johne's disease on their own farm often lacked management capabilities and knowledge (Hop et al., 2011). In contrast, farmers who had experienced mastitis problems or had a relatively high bulk-tank SCC when they were interviewed often felt they had insufficient knowledge about mastitis prevention, which could have led to a loss of confidence in their own knowledge (Kuiper et al., 2005). Especially for novel or emerging diseases, sufficient information might not be available for farmers to make informed decisions (Alarcon et al., 2014).

Feasibility and Practicality. Disease prevention and control measures will be implemented only if farmers perceive them to be feasible and practical (Garforth et al., 2013; Toma et al., 2015; Table 3). For example, dairy cow hoof mats soaked in trademarked chemical solutions were often abandoned because of difficulty manipulating and cleaning them, or because cows were reluctant to walk over them (Relun et al., 2013).

According to farmers, one of the main barriers to implementing new or different management practices was a lack of time to perform them (Garforth, 2011). For example, uptake of recommended Johne's disease control strategies and lameness control activities in sheep and cattle was influenced by time availability (Wassink et al., 2005; Leach et al., 2010a; Sorge et al., 2010a; Roche, 2014; Ritter at al., 2015). However, whereas the expected time requirement was an important barrier to participating in regular herd health management, it was not a key factor in decisions to quit participating (Derks et al., 2012). Furthermore, participants in a Johne's disease control program believed that several management changes actually saved time (Sorge et al., 2010a; Table 3).

The requirement for extra labor can also be an impediment to making on-farm changes, and the cost and availability of skilled labor might impede farmers' implementation of recommended changes (Wassink et al., 2005; Benjamin et al., 2010; Sorge et al., 2010a; Relun et al., 2013; Alarcon et al., 2014; Horseman et al., 2014). After insufficient time, lack of labor was the second most important barrier to lameness control in dairy cattle, with almost half of farmers considering it "extremely important" or "very important" (Leach et al., 2010b).

The impracticality of recommended changes, for instance due to inadequate structural layout of the 
Table 4. Recommendations to enhance the perceived benefits of disease prevention and control

\begin{tabular}{lc}
\hline Recommendation & Reference \\
\hline - Prioritize management suggestions that require low investment but can still reduce risk. & Barkema et al., 2013 \\
- Raise farmers' awareness of the economic and non-economic benefits they can expect when they & Simon-Grifé et al., 2013 \\
successfully implement changes. & Kovich et al., 2006 \\
- Encourage farmers to participate in certification programs and purchase animals only from farms that & \\
are certified. & Valeeva et al., 2007; \\
• Consider financial support for farmers (e.g., for testing, herd visits of veterinary practitioners, or & Lam et al., 2010 \\
implementation of strategies). & Lonsider using incentives or penalties (financial or other) to motivate farmers to achieve predetermined \\
goals. & - Assess producers' views on the perceived negative effects of disease control and work toward solutions \\
that take these concerns into account. & \\
- Address internal drivers, such as farmers' pride or job satisfaction, when motivating them to use best \\
management practices.
\end{tabular}

farm, can be another barrier. Examples include lack of available land and facilities, or inappropriate layout of buildings (Jonsson and Matschoss, 1998; Benjamin et al., 2010; Sorge et al., 2010a; Garforth, 2011; Garforth et al., 2013; Alarcon et al., 2014). Facility restructuring might represent a substantial financial burden, and might not be instantly achievable, but motivated farmers indicated their willingness to make changes as soon as their situation permitted (Ritter et al., 2016). Until they can implement permanent structural changes, some farmers use innovative solutions to decrease the risk of pathogen transmission (e.g., placing a newborn calf in a clean feed or silage cart, which allows the cow to interact with the calf but prevents nursing and limits the calf's contact with cow manure; Godkin and Jansen, 2010; Table 3).

Farmers also take into account the financial situation of their farm when considering change (Gunn et al., 2008; Benjamin et al., 2010; Garforth et al., 2013; Ritter et al., 2015); more capital allows the farmer to hire more labor, build facilities, or acquire recommended tools. For producers, it was important that improved foot health could be achieved by affordable measures, and cost-effectiveness was positively associated with the number of indented foot-health strategies (Bruijnis et al., 2013).

\section{Perceived Benefits and Perceived Disadvantages}

Economic Factors. Farmers' assessment of the expected outcome of a management change and the individually evaluated tradeoff between its perceived benefits and barriers ultimately influence farmers' adoption. One important driver for farmers is perceived cost-effectiveness: strategies are more likely to be implemented if the returns seem to justify them (Fraser et al., 2010; Garforth et al., 2013; Alarcon et al., 2014; Table 4). For example, in the case of bovine viral diarrhea, over $70 \%$ of interviewed South Australian cattle farmers said they would be willing to pay a small cost to participate in a control program if it could be shown that the long-term benefits exceeded the fees (Lanyon et al., 2015).

Most farmers (75\%) interviewed in northwest England believed that having biosecurity measures in place was more cost-effective than treating a disease on-farm (Brennan and Christley, 2013). Similarly, farmers in Great Britain mentioned improved profitability as a key motivator for implementing biosecurity strategies (Gunn et al., 2008). Many dairy farmers that have MAP-positive herds participate in voluntary Johne's disease control programs to avoid production losses. For cattle farms that test negative for MAP, farmers often believe that participating in a certification program results in enhanced marketability of their cattle and that the economic advantages outweigh associated costs (Kovich et al., 2006; Benjamin et al., 2009; Nielsen, 2011; Table 4). However, many cattle producers that purchase animals do not consider the infection status of replacement animals for pathogens such as MAP or bovine leukemia virus (Benjamin et al., 2010; Young et al., 2010b; Ritter et al., 2016). This highlights the importance of farmers' context: the farming industry can determine whether it is worthwhile for farmers to participate in certification programs. In an even broader context, consumer demand can also be a driver for farmers to strive for a certain standard (e.g., retailers might not purchase animal products that do 
not meet a standard). Information about how much farmers are prepared to pay for the purchase of lowrisk replacements instead of animals with unknown or high-risk status is not available. However, studies using "willingness to pay" approaches, as applied in marketing research, could yield new insights (Breidert, 2006; Nayga et al., 2006; Benjamin et al., 2010).

As a way of motivating farmers to take steps toward improved disease detection, prevention, and control, recent control programs have offered financial support, for example by reimbursing farmers for Johne's disease testing or for culling high-titer, MAP-positive cows (Kelton et al., 2014; Table 4). Penalties for not achieving predetermined thresholds have also been suggested, and in the case of bulk-milk SCC, financial penalties have been more effective than financial premiums (Valeeva et al., 2007; Fraser et al., 2010; Table 4). However, relying on these external motivators might cause farmers to participate only as long as the motivators are in place, as observed when industry funding for MAP herd-level testing in the Alberta Johne's Disease Initiative was terminated (unpublished data).

Noneconomic Factors. Besides financial drivers, non-economic motivators are equally - potentially even more -important for many farmers when weighing the advantages and disadvantages of proposed management measures (Garforth and Rehman, 2006; Swinkels et al., 2015; Table 4). For example, Gramig et al. (2010) estimated that $41 \%$ of dairy farmers would adopt dehorning practices that minimized the risk of bovine leukemia virus transmission to uninfected animals, even if adoption of these practices would not avoid financial losses due to this virus. The authors did not assess other factors that might have played a role in that decision. However, studies suggest that enhancing cattle welfare is an important consideration for improving lameness and mastitis management, as well as for controlling zoonotic pathogens (Valeeva et al., 2007; Ellis-Iversen et al., 2010; Leach et al., 2010b; Relun et al., 2013).

One goal of on-farm disease control measures is to enhance animal health. Although $39 \%$ of dairy producers thought their calf and herd health improved after they had implemented at least one strategy for Johne's disease control, some felt that particular recommendations (e.g., immediate removal of the calf from the dam) would compromise animal health and welfare (Sorge et al., 2010a; Table 4). A Swedish study reported that some dairy farmers believed regular exposure to infections could be beneficial to animal health (Frössling and Nöremark, 2016), whereas a justified concern mentioned by cattle farmers in Australia was that reincursion of ticks after eradication would jeopardize their animals' health because of increased risk of tick fever (Jonsson and Matschoss, 1998).

Having a good reputation and taking pride in being a good farm manager with a clean barn, healthy animals, and good husbandry can be motivators for executing best management practices (Hovi et al., 2005; Gunn et al., 2008; Leach et al., 2010b; Nielsen, 2011, Alarcon et al., 2014; Roche, 2014; Table 4). Some farmers go so far as to claim that endemic disease problems are the individual farmer's fault and that "good" farmers do not have these issues (Heffernan et al., 2008). In addition to job satisfaction, which is often regarded as an important motivator in improving dairy cow mastitis, Johne's disease, or lameness (Valeeva et al., 2007; Hop et al., 2011; Bruijnis et al., 2013), internal incentives mentioned for farmers' adoption of strategies included environmental, family, lifestyle, and stewardship motives (Bergevoet et al., 2004; Garforth and Rehman, 2006; Leach et al., 2010b; Table 4). Whereas Valeeva et al. (2007) reported that dairy product quality and image, as well as recognition for a job well done, were the least important motivators for improving mastitis management, Swinkels et al. (2015) concluded that dairy farmers were sensitive to other farmers' social norms and even extended antimicrobial mastitis treatment past the treatment duration recommended by the veterinarian to be a "good farmer." The importance of each of these internal drivers remains uncertain. To gain a more comprehensive understanding of these social factors and their influence on farmer behavior, qualitative methods (as well as traditional quantitative methods) should be applied.

\section{Summary}

Awareness of the presence of a pathogen or disease is not sufficient to motivate management change. Farmers also need to acknowledge that the situation poses a problem that requires action (Wauters and Rojo Gimeno, 2014). Similarly, although sufficient knowledge contributes to farmers' perceived behavioral control and is necessary to adequately implement suggested management practices, we cannot assume that educating farmers about a pathogen and recommended strategies for control is enough to elicit on-farm change. Instead, the perceived effectiveness and feasibility/practicality of a recommended management strategy are key considerations for farmers. Furthermore, they will weigh the perceived advantages of a change against the perceived disadvantages; these considerations involve not only economic factors but also internal drivers such as pride in good farm management, although these drivers have not been extensively studied. The role of farmers' 
perceived responsibility in their prevention and control efforts varies among studies, but farmers are probably more likely to take on responsibility in the form of a joint effort and if they feel sufficiently supported at an organizational or institutional level. In that sense, farmers are not only influenced by their unique circumstances and individual mindsets, but also by external influences such as other farmers, the industry, or government.

\section{EXTENSION AND COMMUNICATION}

Motivating farmers to improve disease prevention and control requires an understanding of the factors that influence farmers' decision-making and a firm knowledge of which information sources pertaining to farm management are most effective at reaching farmers, and at providing effective support to facilitate on-farm changes (Garforth et al., 2004). Importantly, these information sources and social referents not only provide farmers with technical knowledge, they also create an expected standard or norm that might cause farmers to experience social pressure, and motivate them to adopt recommended management strategies (Öhlmér et al., 1998; Lindberg et al., 2006; Lam et al., 2007; Rehman et al., 2007).

The amount of information and the information sources available to farmers are extensive and continually increasing (Alarcon et al., 2014). However, more than half of dairy farmers surveyed in Ireland reported that a lack of information might prevent improvements in biosecurity measures (Sayers et al., 2013), and less than half of South Australian cattle farmers knew where to find clear information about bovine viral diarrhea prevention or control (Lanyon et al., 2015). These examples show that farmers' information-seeking behaviors do not align with existing dissemination pathways.

The accessibility of sources is a necessary precursor to obtaining information, but the credibility of the information source is also an important consideration for farmers (Garforth, 2015). Understanding the extension media at farmers' disposal, their individual preferences, and their context can help to determine the best way to communicate with producers. In this second part of the review, we discuss the main communication tools and approaches used in agricultural extension, as well as the challenges of within-farm communication and the provision of research results and advice to farmers. To capture a wider understanding of the methods, tools, and approaches used to motivate on-farm change, we reviewed any literature outlining agricultural extension approaches, and did not restrict the review to research on agricultural extension related to the prevention and control of infectious animal diseases. We have also provided recommendations for optimizing agricultural extension (Tables 5 and 6 ).

\section{Tools}

Mass Media. Information that is widely accessible and often distributed nationally or regionally has the advantage of reaching a broad range of producers (Table 5 and Figure 2). Printed media and literature are among the preferred information sources for dairy farmers in the Netherlands (Derks et al., 2013a) and the United States (Russell and Bewley, 2011), and information from the farming press is often regarded as upto-date and relevant (Garforth et al., 2013). Similarly,

Table 5. Recommendations to enhance the success of extension tools

\begin{tabular}{|c|c|}
\hline Recommendation & Reference \\
\hline $\begin{array}{l}\text { - Prepare farm advisors to educate farmers about disease control and clarify their role in disease control } \\
\text { programs. Provide educational materials free of charge. }\end{array}$ & $\begin{array}{l}\text { Sorge et al., 2010b; } \\
\text { Ellis-Iversen et al., } 2010\end{array}$ \\
\hline - Train veterinary practitioners and other farm advisors in effective communication skills. & Adams and Kurtz, 2016 \\
\hline - Consider using peripheral extension tools, potentially in cooperation with commercial companies. & Jansen et al., 2010b \\
\hline $\begin{array}{l}\text { - Provide educational materials and training programs for farmers and employees (if applicable, account } \\
\text { for different languages and cultural backgrounds). }\end{array}$ & $\begin{array}{l}\text { Izak et al., 2011; } \\
\text { Schewe et al., } 2015\end{array}$ \\
\hline
\end{tabular}


Table 6. Recommendations to enhance links between research and agricultural extension

\begin{tabular}{ll}
\hline Recommendation & Reference \\
\hline - Provide farmers and stakeholders with relevant data from their own farm or farms in their region. & Lindberg et al., 2006 \\
- Record preintervention status at the herd and national level, and monitor changes of recorded parameters & Bell et al., 2006; \\
(e.g., disease incidence or prevalence baseline, adoption of relevant management practices). Where feasible, & Raizman et al., 2006 \\
consider routine data collection procedures to facilitate progress and offer benchmarking tools. & Mee, 2007 \\
- Publish and translate relevant research findings into applicable management solutions that are SMART & \\
(specific, measurable, achievable, realistic/relevant, and time-bound). & \\
- Publish and translate relevant research findings into easy-to-understand text and video messages for farm \\
journals and social media. & Brightling et al., 2009; \\
- Deliver consistent messages that are applicable without modification across the industry. Consider & Wilson et al., 2015; \\
developing a central independent body that works with producer input to devise these messages. & Moore et al., 2008 \\
- Include stakeholders, social scientists, and communication specialists during the development and delivery & Jansen and Lam, 2012; \\
of a prevention and control program. & Klerkx et al., 2012; \\
\hline
\end{tabular}

$77 \%$ of cattle producers in England regarded research papers and journals among their preferred sources of biosecurity information, and $38 \%$ of those stated that they were most likely to take advice from these sources (Brennan and Christley, 2013). Conversely, television shows and the radio, although used by some, are generally not among farmers' preferred information sources (Heffernan et al., 2008; Brennan and Christley, 2013; Frössling and Nöremark, 2016). Similarly, Internet sources such as social media (i.e., Twitter or Facebook), blogs, podcasts, and webinars are often less preferred, although $40 \%$ of Swedish farmers appreciated the websites of animal health organizations and associations (Brennan and Christley, 2013; Frössling and Nöremark, 2016). However, with the growing use of the Internet for personal and professional purposes, we can expect that it will gain popularity. In 2014, $89 \%$ of Canadian dairy producers accessed the Internet for dairy information, mostly through search engines (Canadian National Dairy Survey 2014, unpublished data). Additionally, the success of computer- and web-based programs has been demonstrated in human health and agricultural contexts (e.g., Krebs et al., 2010; Merkel and Gipson, 2011; Peels et al., 2014). In particular, the potential for reaching large audiences while customizing messages to individuals' attitudes, goals, motivators, and barriers ("tailoring"), an approach used for health behavior interventions, could be useful in the farming context (Noar et al., 2007).

Some farmers perceive information access via mass media as overwhelming, and often regard the advice provided as impractical and irrelevant for their own farm (Ellis-Iversen et al., 2010; Garforth et al., 2013). This perception could lead farmers to ignore advice from central sources, or could reinforce negative attitudes about the information provided (Garforth, 2015). Research on livestock farmers' attitudes about government-derived information is scarce in countries other than the United Kingdom, but farmers often do not see information from this source as important, useful, or credible (Gunn et al., 2008; Heffernan et al., 2008; Hernández-Jover et al., 2012). They commonly consider government information to be relevant only for notifiable diseases and national disease emergencies (Garforth et al., 2013; Alarcon et al., 2014). More research is needed on the perceived trustworthiness of information delivered via mass media. Furthermore, the effectiveness of Internet-based interventions should be further assessed in the agricultural context.

Seminars and Conferences. Many studies assessing farmers' use of and preferences for information

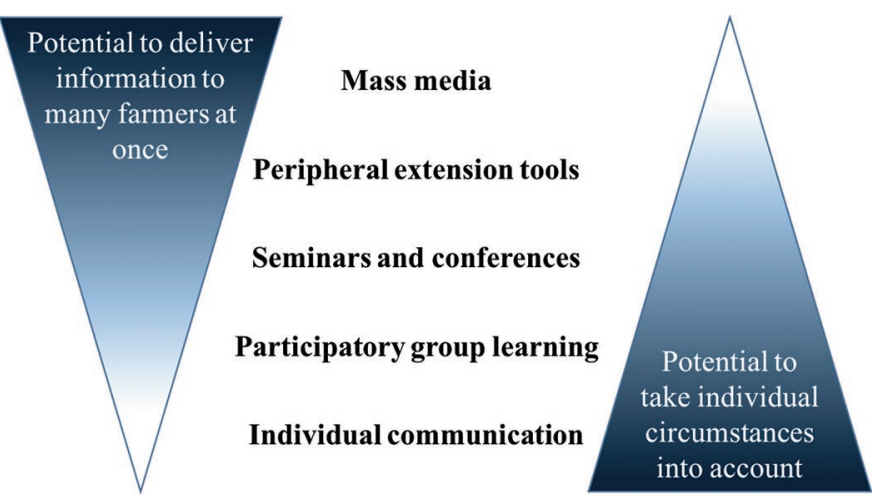

Figure 2. Potential of agricultural extension tools to deliver information simultaneously to many farmers and tailor communication according to individual circumstances. Color version available online. 
sources do not include farmers' perceptions of events where information is delivered to a large farmer audience (i.e., large-scale seminars and conferences; Kuiper et al., 2005; Heffernan et al., 2008; Derks et al., 2013a). Other studies report that these events are often less preferred, and may be less frequently used (Brennan and Christley, 2013; Ritter et al., 2015). Seminars and conferences offer a chance for producers to interact with each other and obtain subject matter from a variety of experts, and some producers highly appreciate them, but location, cost, and time away from the farm are barriers to attendance (Chase et al., 2006; Table 5 and Figure 2). This might explain why $28 \%$ of all interviewed dairy farmers in Kentucky indicated that they never attended meetings, but that $56 \%$ of those farmers rated local or regional meetings as one of their preferred information delivery methods (Russell and Bewley, 2011).

Participatory Group Learning. Collective learning approaches allow farmers to share ideas and experiences, and often include on-farm learning through workshops, field days, or farm tours (Black, 2000; Andreata, 2001; Figure 2). In Ontario, Canada, "Focus Farms" aimed at improving Johne's disease management by implementing an experiential learning process that used veterinarian-facilitated meetings involving table discussions, farm tours, and specific learning activities/games (Roche et al., 2015). Participating farmers improved their knowledge about Johne's disease, and $81 \%$ reported implementing at least one on-farm change, compared with only $38 \%$ of farmers who did not participate (Roche et al., 2015). Obtaining tailored information and advice from their peers - who are perceived to be "equal" and to understand farming realities - is likely one of the reasons for increased implementation rates with this method of learning.

Farmer discussion groups are a flexible way to allow groups to explore a variety of issues with the goals of creating a sense of ownership and bridging the gap between scientific information and on-farm practices (Ivemeyer et al., 2015; Table 5). Farmers who participate in discussion groups or health schemes/clubs highly value these extension tools and list them among their most preferred and useful communication methods for disease issues (Jonsson and Matschoss, 1998; Vaarst et al., 2007; Alarcon et al., 2014). For example, farmer discussion groups have been proposed to decrease mastitis and lameness in dairy cows, or to discuss sow group housing (Leach et al., 2010b; Lam et al., 2011; de Lauwere et al., 2012). After 6 mo attending discussion groups for dairy farmers in the Netherlands, $72 \%$ of study group participants used a standard treatment schedule to improve udder health, compared with only $58 \%$ of non-participants (Lam et al., 2007).
"Demonstration farms" provide sites for agricultural extension and training, and can be used to showcase specific management techniques and practices. "Monitor farms" also give farmers the option of becoming involved in decision-making for these farms when aiming to improve productivity, profitability, and sustainability. Along the way, farmers can compare their own farm performance, share experiences, and learn from examples (Campbell et al., 2006; Scottish Monitor Farms Programme, 2014). Similarly, "demonstration projects" can be used to assess the outcomes of corresponding methods or processes applied to several farms (Piepers et al., 2011; Erskine et al., 2015) Numerous variations of these 3 approaches exist, but they are generally underpinned by participatory learning or participatory action research.

Although participatory group learning has the advantage of drawing from collective knowledge, it requires farmers to openly share their opinions and experiences, and this might be difficult to achieve (Black, 2000; Alarcon et al., 2014). Furthermore, the potentially large number of opinions and choices presented to farmers during interactive learning might result in high levels of uncertainty, and inhibit farmers' intentions to change management (Hansson and Ferguson, 2011). A person familiar with farming (e.g., a veterinary practitioner or production advisor) who has received facilitation training should therefore moderate discussions (Vaarst et al., 2007; Lam et al., 2011; Roche et al., 2015).

Individual Communication. Farmers are more inclined to act in response to information that is tailored to their individual circumstances (Garforth, 2015). One-on-one communication between the farmer and their social referents allows for the personalization of information and advice to fit each farmer's approach (Kristensen and Jakobsen, 2011a; Santman-Berends et al., 2014; Table 5 and Figure 2). Referents, and farmers' preferences for their advice vary for each producer, but include veterinary practitioners, colleagues, nutritionists, hoof trimmers, DHI personnel, feed representatives, milk equipment advisors, product salespeople, inseminators, researchers, contractors, farm staff, family, friends, and neighbors (Jansen et al., 2010c; Leach et al., 2010a; Relun et al., 2013; Lindahl et al., 2015; Ritter et al., 2015; Wilson et al., 2015; Frössling and Nöremark, 2016). The majority of studies recognize that peers affect farmers' decision-making (Lindberg et al., 2006; Lam et al., 2007; Elliot et al., 2011; Hansson and Ferguson, 2011; Swinkels et al., 2015), but a United Kingdom study reported that what others were saying or doing had little influence on farmers' prevention and control efforts (Garforth et al., 2013).

Further research is needed into the effect of farmers' social network on their management decisions (Bur- 
ton, 2004; Hansson and Ferguson, 2011), but it is well established that veterinary practitioners often have a profound influence on farmers' decision-making due to their generally good relationship with the farmer and the farmer's trust in their advice (e.g., Jansen et al., 2010c; Young et al., 2010a; Derks et al., 2013a; Sayers et al., 2013; Alarcon et al., 2014). Regular interactions between a farmer and a herd veterinarian increase familiarity with each other's beliefs, values, and aspirations, and enhance trust (Jansen and Lam, 2012; Table $5)$. Even when farmers receive information or advice from other sources, they commonly follow up or check with their local practitioner (Garforth, 2011; Garforth et al., 2013). In one study, if the herd veterinarian thought a mastitis treatment schedule was important, farmers generally agreed (Lam et al., 2007). In others, the veterinarian's advice has been instrumental in decreasing antibiotic usage in cattle (Jones et al., 2015), and in farmers' decisions about whether or not to enroll in a voluntary Johne's disease control program (Hop et al., 2011; Ritter et al., 2015). The majority of farmers stated that they would most likely adopt biosecurity strategies or implement a control program if it was recommended by their herd veterinarian (Ellis-Iversen et al, 2010; Brennan and Christley, 2013). These high levels of trust and confidence mean that farmers (selfreportedly) take up their veterinarians' advice in more than $80 \%$ of cases (Derks et al., 2013a; Table 5).

Although many farmers believe that their herd veterinarian works for and with them, negative perceptions mentioned by farmers include a lack of specialized veterinary knowledge or insufficient provision of information by their veterinarian (Kaler and Green, 2013; Alarcon et al., 2014; Table 5). Furthermore, more than $30 \%$ of sheep and cattle veterinarians believed that uptake of on-farm biosecurity measures was inadequate due to a lack of veterinary time, interest in, or knowledge of farm-level biosecurity measures (Gunn et al., 2008). These perceptions could explain why many cattle and sheep farmers in the United Kingdom interact with their herd veterinarian only "occasionally" or "as needed," and only 12\% of Australian cattle farmers regarded veterinary practitioners as the most useful method of communication (Jonsson and Matschoss, 1998; Heffernan et al., 2008). Even if the farmer-veterinarian relationship is good and veterinarians have excellent technical knowledge, their success at motivating farm changes will depend on their skills to effectively communicate advice (Mee, 2007; Noordhuizen et al., 2008a,b; Atkinson, 2010b; Adams and Kurtz, 2016; Table 5). Unfortunately, the communication skills of veterinary practitioners appear to be less than optimal (Kristensen and Enevoldsen, 2008; Jansen et al., 2010a;
Derks et al., 2013b; Cipolla and Zecconi, 2015). This may lead to inadequate uptake of advice, because the farmers are not sufficiently guided in their decision or because veterinarian and farmer have different perceptions of the feasibility of proposed management changes (Sorge et al., 2010a; Roche, 2014).

Peripheral Extension Tools. The effect of central routes of communication (i.e., routes that assume farmers make rational decisions when approached by the right advisors and presented with the right arguments) will be limited for farmers who are not motivated enough to adopt suggested changes (Jansen et al., 2010b; de Lauwere et al., 2012). For these farmers, a peripheral approach, as extensively studied in social science and often used in marketing, sales, or advertising, can be very effective. Peripheral routes of communication use cues, heuristics, or "nudges" instead of comprehensive science-based argumentation to unconsciously elicit the desired behavior (Cialdini, 2001). The peripheral approach is especially suitable for altering single management practices. For example, a Dutch national mastitis campaign provided farmers with free glove samples, sent humorous postcards reminding farmers to wear gloves during milking, and gave discounts on gloves from the campaign website (Jansen et al., 2010b). During the campaign, the use of milking gloves increased substantially and farmers' attitudes about their use became more positive, which could explain why they continued to use gloves a year after the start of the campaign. It might be worthwhile to consider cooperation with commercial companies (e.g., glove manufacturers) that want to sell their products and have expertise in marketing (Jansen and Lam, 2012; Table 5).

\section{Within-Farm Communication}

Management decisions on the farm are often not the responsibility of only one person. Family members or an employed farm manager might have an important influence and should be involved in decision-making (Barkema et al., 2013). However, even after decisions have been made, management is often carried out by others (e.g., farm workers not involved in the decisionmaking; Blackstock et al., 2007). A lack of communication between decision-makers and workers is likely associated with a lack of on-farm biosecurity uptake, especially if the personnel are unaware of decisions made, of disease transmission pathways, and of the reasons for measure implementation (Vaillancourt and Carver, 1998; Racicot et al., 2012b; Table 5).

The implementation of standard operating procedures and engagement of employees are important aspects of 
farm management to ensure consistent herd performance and prevent disease (Reneau, 2001; Cavazos, 2003; Barkema et al., 2015; Schewe et al., 2015). For example, dairy cows' udder health could be improved by implementing communication strategies for milkers (delivered by veterinarians and consultants on mastitis control), as well as by strictly enforcing protocols and (financial) penalties if bulk-tank SCC increased (Izak et al., 2011; Schewe et al., 2015).

The education and engagement of foreign farm personnel can be a major challenge because of different languages and cultural backgrounds (Atkinson, 2010a; Barkema et al., 2013; Table 5). Latino employees from 12 Michigan dairy farms were 3 times less likely to believe they had learned milk protocols from herd owners or managers (as opposed to learning from other employees or being self-taught) and 4 times less likely to know the SCC goals of the dairy farm than English-speaking employees (Erskine et al., 2015). Whereas simple visible cues (e.g., signs, cameras) have been proven to increase compliance with recommended procedures for hand hygiene in hospitals and with biosecurity strategies on poultry farms, it is doubtful whether these cues have a lasting effect, and more sustainable strategies need to be developed (Racicot et al., 2012a; Smiddy et al., 2015). We can assume that farm employees' reasons to perform recommended biosecurity measures (or not) are as diverse as their employers' reasons, and more research into the knowledge, attitudes, and compliance of farm employees relating to recommended practices will help improve adherence to farmers' management strategies (Delabbio, 2006).

\section{Dissemination of Research Results and Advice to Farmers}

Research is important for generating new knowledge and providing farmers with best management recommendations. The presentation of research findings about disease control programs can also increase farmers' awareness of available programs (Tsui et al., 2006). Furthermore, for any herd health intervention program, the accurate detection and characterization of the current situation is essential for estimating changes and providing feedback on the success of the intervention (Bell et al., 2006; Huijps et al., 2009). Allowing farmers and stakeholders timely access to updated and accurate information about disease status for their own herd, as well as at a national/provincial level, enables them to compare their performance (i.e., benchmarking), make informed decisions, and may motivate on-farm changes (Lindberg et al., 2006; Østerås and Sølverød, 2009; Table 6).
Although farmers generally appreciate research and have faith in its credibility (Sorge et al., 2010a; Garforth et al., 2013), they are often unaware of current studies being done by universities and criticize the lack of communication of relevant research findings (Alarcon et al., 2014; Table 6). Furthermore, some farmers disapprove of how findings are translated to recommended management strategies and question the relevance of the research being conducted (Garforth et al., 2013; Alarcon et al., 2014; Table 6). A comparison of educational materials on the Internet revealed that recommendations about biosecurity measures for different species and classes of livestock contained substantial variations by source, as well as within and among commodity groups (Moore et al., 2008). Furthermore, the biosecurity-related opinions and practices of dairy service providers (i.e., veterinary practitioners and dairy advisors) were often inconsistent, and communication across these groups was poor (Sayers et al., 2014; Table 6 ). These discrepancies could lead to confusion among farmers and farm advisors, and may serve as justification to avoid implementing management changes or to select only a few recommendations that are insufficient to effectively reduce disease transmission (Moore et al., 2008; Wilson et al., 2015). In particular, if farm management recommendations are developed by different sources, inconsistencies in terminology use and interpretation can lead to confusion that inhibits desired uptake (Moore et al., 2008; Brightling et al., 2009).

\section{Summary}

Farmers differ in their preferences for receiving information about farm management and disease prevention and control. A range of extension tools should be used in conjunction to deliver status updates and consistent management recommendations that are relevant and practical for the farmer (Jansen et al., 2010c; Ritter et al., 2015). Whereas mass media can be used to easily distribute information to a broad audience, more personal approaches such as discussion groups or one-onone communication are likely to have a greater effect on motivating on-farm change. Still, further research is needed to investigate the extent and character of discussions about disease prevention and control between farmers and their advisors, and whether communication training for farm advisors (or prospective farm advisors) can positively influence farmer behavior (Derks et al., 2013a; Pritchard et al., 2015). Peripheral routes of communication can reach farmers who are not motivated by external or internal drivers. In this area, veterinary medicine can learn from social science and should further confirm the applicability of peripheral communication for the livestock sector. 
Motivating on-farm decision-makers to adopt recommended management practices is important, but adequate implementation of management strategies by farm personnel is also necessary to decrease risk of pathogen transmission. Agricultural communication should, therefore, also include farm personnel.

\section{CONCLUSIONS}

Socio-psychological factors are important in farmers' adoption of recommended management strategies, and disease prevention and control interventions need to be based on theoretical frameworks that incorporate these factors. Farmers' unique circumstances affect every decision about adopting a management strategy; their awareness of problems, and the perceived effectiveness and feasibility of recommended strategies are certain to play important roles in farmers' decision to change. The magnitude of the effect of influences such as farmers' internal drivers (e.g., their sense of responsibility, pride or perceived social pressure) and their perceived behavioral control should be investigated further, although evidence for their importance is available. Farmers are not an isolated group; they are influenced by their context, which can impede or facilitate on-farm changes. To effectively inform farmers about recommended management measures, a range of extension tools should be used to deliver consistent, easily accessible, relevant, and practical information. In particular, more personal means of communication can move beyond simple education and take farmers' individual beliefs, goals, and constraints into account. Because of the complexity of designing and implementing interventions to motivate uptake of recommended strategies and because of the highly socio-psychological nature of human behavior, we recommend collaboration of stakeholders and an interdisciplinary approach that includes social scientists, communication specialists, and marketing experts.

\section{ACKNOWLEDGMENTS}

This study was funded by Canada's Natural Sciences and Engineering Research Council (NSERC) Industrial Research Chair Program, with industry contributions from Alberta Milk (Edmonton, AB, Canada), the Dairy Farmers of Canada (Ottawa, ON, Canada), the Dairy Farmers of Manitoba (Winnipeg, MB, Canada), the British Columbia Dairy Association (Burnaby, BC Canada), Westgen Endowment Fund (Milner, BC, Canada), the Canadian Dairy Network (Guelph, ON, Canada), and CanWest DHI (Guelph, ON, Canada). The authors thank Dr. John Kastelic for editing the manuscript.

\section{REFERENCES}

Adams, C. L., and S. Kurtz. 2016. Skills for Communicating in Veterinary Medicine. 1st ed. MHRI Publishing, Parsippany, NJ.

Ajzen, I. 1991. The theory of planned behavior. Organ. Behav. Hum. Dec. 50:179-211.

Alarcon, P., B. Wieland, A. L. Mateus, and C. Dewberry. 2014. Pig farmers' perceptions, attitudes, influences and management of information in the decision-making process for disease control. Prev. Vet. Med. 116:223-242.

Anderson, J. R., and G. Feder. 2004. Agricultural extension: Good intentions and hard realities. World Bank Res. Obs. 19:41-60.

Andreata, S. M. 2001. Learning from the group: A case study of the focus farm project in Gippsland, Victoria. MSc Thesis. University of Melbourne, Australia.

Atkinson, O. 2010a. Communication in farm animal practice 1. Farmer-vet relationships. In Pract. 32:114-117.

Atkinson, O. 2010b. Communication in farm animal practice 2. Effecting change. In Pract. 32:163-165.

Barkema, H. W., S. De Vliegher, S. Piepers, and R. N. Zadoks. 2013. Herd level approach to high bulk milk somatic cell count problems in dairy cattle. Vet. Q. 33:82-93.

Barkema, H. W., M. A. G. von Keyserlingk, J. P. Kastelic, T. J. G. M. Lam, C. Luby, J.-P. Roy, S. J. LeBlanc, G. P. Keefe, and D. F. Kelton. 2015. Invited review: Changes in the dairy industry affecting dairy cattle health and welfare. J. Dairy Sci. 98:7426-7445.

Bell, N. J., M. J. Bell, T. G. Knowles, H. R. Whay, D. J. Main, and A. J. Webster. 2009. The development, implementation and testing of a lameness control programme based on HACCP principles and designed for heifers on dairy farms. Vet. J. 180:178-188.

Bell, N. J., D. C. J. Main, H. R. Whay, T. G. Knowles, M. J. Bell, and A. J. F. Webster. 2006. Herd health planning: Farmers' perceptions in relation to lameness and mastitis. Vet. Rec. 159:699-705.

Benjamin, L. A., G. T. Fosgate, M. P. Ward, A. J. Roussel, R. A Feagin, and A. L. Schwartz. 2009. Benefits of obtaining testnegative Level 4 classification for beef producers in the Voluntary Bovine Johne's Disease Control Program. Prev. Vet. Med. 91:280-284.

Benjamin, L. A., G. T. Fosgate, M. P. Ward, A. J. Roussel, R. A. Feagin, and A. L. Schwartz. 2010. Attitudes towards biosecurity practices relevant to Johne's disease control on beef cattle farms. Prev. Vet. Med. 94:222-230.

Bergevoet, R. H. M., C. J. M. Ondersteijn, H. W. Saatkamp, C. M. J. van Woerkum, and R. B. M. Huirne. 2004. Entrepreneurial behaviour of Dutch dairy farmers under a milk quota system: Goals, objectives and attitudes. Agric. Syst. 80:1-21.

Bigras-Poulin, M., A. H. Meek, S. W. Martin, and I. McMillan. 1985. Attitudes, management practices, and herd performance - a study of Ontario dairy farm managers. II. Associations. Prev. Vet. Med. $3: 241-250$.

Black, A. W. 2000. Extension theory and practice: A review. Aust. J. Exp. Agric. 40:493-502.

Blackstock, K., K. Brown, R. Burton, R. Dilley, B. Slee, J. Dywer, J. Ingram, J. Mills, and J. Taylor. 2007. Good practice guide: Influencing environmental behaviour using advice. Accessed Nov. 12, 2016. http://www.programme3.ac.uk/water/ P345GoodPracticeGuide.pdf.

Breidert, C. 2006. Estimation of Willingness-to-Pay. Deutscher Universitätverlag, Wiesbaden, Germany.

Brennan, M. L., and R. M. Christley. 2013. Cattle producers' perceptions of biosecurity. BMC Vet. Res. 9:71.

Brightling, P., R. Dyson, A. Hope, and J. Penry. 2009. A national programme for mastitis control in Australia: Countdown Downunder. Ir. Vet. J. 62:S52-S58.

Bruijnis, M., H. Hogeveen, C. Garforth, and E. Stassen. 2013. Dairy farmers' attitudes and intentions towards improving dairy cow foot health. Livest. Sci. 155:103-113.

Burton, R. J. F. 2004. Reconceptualising the 'behavioural approach' in agricultural studies: a socio-psychological perspective. J. Rural Stud. 20:359-371. 
Campbell, S., D. Counsell, D. Friend, R. Thompson, S. Ackland, and S. Barrington. 2006. Monitor farms as a tool for practice change the $8 \times 5$ Wool Profit Program experience. Accessed Nov. 12, 2016. http://www.regional.org.au/au/apen/2006/refereed/1/3065_ campbells.htm.

Casal, J., A. De Manuel, E. Mateu, and M. Martin. 2007. Biosecurity measures on swine farms in Spain: Perceptions by farmers and their relationship to current on-farm measures. Prev. Vet. Med. $82: 138-150$.

Cavazos, F. G. 2003. Useful ideas and principles for the implementation of reinforcement programs to keep milkers motivated. Pages 77-85 in Proc. 42nd Annu. Mtg. Natl. Mastitis Counc., Fort Worth, TX. Natl. Mastitis Counc., Inc., New Prague, MN.

Chase, L. E., L. O. Ely, and M. F. Hutjens. 2006. Major advances in extension education programs in dairy production. J. Dairy Sci. 89:1147-1154

Cialdini, R. B. 2001. Influence: Science and Practice. 4th ed. Allyn \& Bacon, Needham Heights, MA.

Cipolla, M., and A. Zecconi. 2015. Short communication: Study on veterinarian communication skills preferred and perceived by dairy farmers. Res. Vet. Sci. 99:60-62.

de Lauwere, C., M. van Asseldonk, J. van't Riet, J. de Hoop, and E. ten Pierick. 2012. Understanding farmers' decisions with regard to animal welfare: The case of changing to group housing for pregnant sows. Livest. Sci. 143:151-161.

Delabbio, J. 2006. How farm workers learn to use and practice biosecurity. J. Extension 44:6FEA1.

Derks, M., L. M. van de Ven, T. van Werven, W. D. J. Kremer, and H. Hogeveen. 2012. The perception of veterinary herd health management by Dutch dairy farmers and its current status in the Netherlands: A survey. Prev. Vet. Med. 104:207-215.

Derks, M., T. van Werven, H. Hogeveen, and W. D. J. Kremer. 2013a. Veterinary herd health management programs on dairy farms in the Netherlands: Use, execution, and relations to farmer characteristics. J. Dairy Sci. 96:1623-1637.

Derks, M., B. van Woudenbergh, M. Boender, W. Kremer, T. van Werven, and H. Hogeveen. 2013b. Veterinarian awareness of farmer goals and attitudes to herd health management in The Netherlands. Vet. J. 198:224-228.

Edwards-Jones, G. 2006. Modelling farmer decision making: Concepts, progress and challenges. Anim. Sci. 82:783-790.

Ekboir, J. M. 1999. The role of the public sector in the development and implementation of animal health policies. Prev. Vet. Med. 40:101-115.

Elliott, J., J. Sneddon, J. A. Lee, and D. Blache. 2011. Producers have a positive attitude toward improving lamb survival rates but may be influenced by enterprise factors and perceptions of control. Livest. Sci. 140:103-110.

Ellis-Iversen, J., A. J. C. Cook, E. Watson, M. Nielen, L. Larkin, M. Wooldridge, and H. Hogeveen. 2010. Perceptions, circumstances and motivators that influence implementation of zoonotic control programs on cattle farms. Prev. Vet. Med. 93:276-285.

Erskine, R. J., R. O. Martinez, and G. A. Contreras. 2015. Cultural lag: A new challenge on dairy farms in the U.S. J. Dairy Sci. 98:8240-8244.

Fransen, G. A., I. Mesters, M. J. Janssen, J. A. Knottnerus, and J. W. Muris. 2009. Which patient-related factors determine selfperceived patient adherence to prescribed dyspepsia medication? Health Educ. Res. 24:788-798.

Fraser, R. W., N. T. Williams, L. F. Powell, and A. J. Cook. 2010. Reducing Campylobacter and Salmonella infection: Two studies of the economic cost and attitude to adoption of on-farm biosecurity measures. Zoonoses Public Health 57:e109-e115.

Frössling, J., and M. Nöremark. 2016. Differing perceptions-Swedish farmers' views of infectious disease control. Vet. Med. Sci. 2:54-68.

Garforth, C. 2015. Livestock keepers' reasons for doing and not doing things which governments, vets and scientists would like them to do. Zoonoses Public Health 62(Suppl. 1):29-38.

Garforth, C., and T. Rehman. 2006. Research to understand and model the behaviour and motivations of farmers in responding to policy changes (England). Accessed Nov. 12, 2016. http:// webarchive.nationalarchives.gov.uk /20130123162956/http:/www. defra.gov.uk/evidence/economics/foodfarm/reports/documents/ Behaviour.pdf.

Garforth, C., T. Rehman, K. McKemey, R. Tranter, R. Cooke, C. Yates, J. Park, and P. Dorward. 2004. Improving the design of knowledge transfer strategies by understanding farmer attitudes and behaviour. J. Farm Manage. 12:17-32.

Garforth, C. J. 2011. Effective communication to improve udder health: Can social science help? Pages 55-66 in Udder Health and Communication. H. Hogeveen and T. J. G. M. Lam, ed. Wageningen Academic Publishers, Wageningen, the Netherlands.

Garforth, C. J., A. P. Bailey, and R. B. Tranter. 2013. Farmers' attitudes to disease risk management in England: A comparative analysis of sheep and pig farmers. Prev. Vet. Med. 110:456-466.

Godkin, A., and J. Jansen. 2010. Practice tips from producers: Raising healthy, Johne's-free heifers. Ontario Ministry of Agriculture, Food and Rural Affairs. Accessed Nov. 12, 2016. http://johnes. ca/pdf\%20files/Practise\%20Tips\%20for\%20calf\%20protection $\% 20$ Factsheet.pdf.

Gramig, B. M., C. A. Wolf, and F. Lupi. 2010. Understanding adoption of livestock health management practices: The case of bovine leukosis virus. Can. J. Agric. Econ. 58:343-360.

Gunn, G. J., C. Heffernan, M. Hall, A. McLeod, and M. Hovi. 2008. Measuring and comparing constraints to improved biosecurity amongst GB farmers, veterinarians and the auxiliary industries. Prev. Vet. Med. 84:310-323.

Hansson, H., and R. Ferguson. 2011. Factors influencing the strategic decision to further develop dairy production-A study of farmers in central Sweden. Livest. Sci. 135:110-123.

Heffernan, C., L. Nielsen, K. Thomson, and G. Gunn. 2008. An exploration of the drivers to bio-security collective action among a sample of UK cattle and sheep farmers. Prev. Vet. Med. 87:358-372.

Hernández-Jover, M., J. Gilmour, N. Schembri, T. Sysak, P. K. Holyoake, R. Beilin, and J. A. Toribio. 2012. Use of stakeholder analysis to inform risk communication and extension strategies for improved biosecurity amongst small-scale pig producers. Prev. Vet. Med. 104:258-270.

Hoe, F. G., and P. L. Ruegg. 2006. Opinions and practices of Wisconsin dairy producers about biosecurity and animal well-being. J. Dairy Sci. 89:2297-2308.

Hogeveen, H., K. Huijps, and T. J. Lam. 2011. Economic aspects of mastitis: New developments. N. Z. Vet. J. 59:16-23.

Hop, G. E., A. G. J. Velthuis, and K. Frankena. 2011. Assessing Dutch farmers' incentives to join a voluntary Johne's Disease programme. Wagen. J. Life Sci. 58:57-64.

Horseman, S., E. Roe, J. Huxley, N. Bell, C. Mason, and H. Whay. 2014. The use of in-depth interviews to understand the process of treating lame dairy cows from the farmers' perspective. Anim. Welf. 23:157-165.

Hovi, M., A. McLeod, and G. Gunn. 2005. Assessing UK farmer attitudes to biosecurity on sheep and cattle farms. Res. Vet. Sci 78(Suppl. A):24.

Huijps, K., H. Hogeveen, T. J. Lam, and R. B. Huirne. 2009. Preferences of cost factors for mastitis management among Dutch dairy farmers using adaptive conjoint analysis. Prev. Vet. Med. 92:351-359.

Ivemeyer, S., N. J. Bell, J. Brinkmann, K. Cimer, E. Gratzer, C. Leeb, S. March, C. Mejdell, S. Roderick, G. Smolders, M. Walkenhorst, C. Winckler, and M. Vaarst. 2015. Farmers taking responsibility for herd health development - stable schools in research and advisory activities as a tool for dairy health and welfare planning in Europe. Org. Agr. 5:135-141.

Izak, E., E. Castello, and G. Veneranda. 2011. Impact of communication strategies for milkers on udder health program. Page 167 in Udder Health and Communication. Wageningen Academic Publishers, Utrecht, Netherlands.

Jansen, J., H. Klinkert, R. J. Renes, and T. J. G. M. Lam. 2010a. Effective communication of veterinary advice: Interaction between the veterinarian and the farmer. Pages 185-191 in Mastitis Research into Practice: Proc. 5th IDF Mastitis Conf. J. E. Hillerton, ed. Vetlearn, Christchurch, New Zealand. 
Jansen, J., and T. J. G. M. Lam. 2012. The role of communication in improving udder health. Vet. Clin. North Am. Food Anim. Pract. 28:363-379.

Jansen, J., R. J. Renes, and T. J. G. M. Lam. 2010b. Evaluation of two communication strategies to improve udder health management. J. Dairy Sci. 93:604-612.

Jansen, J., C. D. M. Steuten, R. J. Renes, N. Aarts, and T. J. G. M. Lam. 2010c. Debunking the myth of the hard-to-reach farmer: Effective communication on udder health. J. Dairy Sci. 93:1296-1306.

Jansen, J., B. H. P. Van den Borne, R. J. Renes, G. Van Schaik, T. J. G. M. Lam, and C. Leeuwis. 2009. Explaining mastitis incidence in Dutch dairy farming: The influence of farmers' attitudes and behaviour. Prev. Vet. Med. 92:210-223.

Jansen, J., G. Van Schaik, R. J. Renes, and T. J. G. M. Lam. 2010d. The effect of a national mastitis control program on the attitudes, knowledge and behavior of farmers in the Netherlands. J. Dairy Sci. 93:5737-5747.

Jansen, J., R. J. Wessels, and T. J. G. M. Lam. 2016. Understanding the mastitis mindset: applying social psychology in practice. Pages 5-15 in Proc. 55nd Ann. Mtg Natl. Mastitis Counc., Glendale, AZ. Natl. Mastitis Counc. Inc., New Prague, MN.

Janz, N. K., and M. H. Becker. 1984. The Health Belief Model: A decade later. Health Educ. Q. 11:1-47.

Jones, P. J., E. A. Marier, R. B. Tranter, G. Wu, E. Watson, and C. J. Teale. 2015. Factors affecting dairy farmers' attitudes towards antimicrobial medicine usage in cattle in England and Wales. Prev. Vet. Med. 121:30-40.

Jonsson, N. N., and A. L. Matschoss. 1998. Attitudes and practices of Queensland dairy farmers to the control of the cattle tick, Boophilus microplus. Aust. Vet. J. 76:746-751.

Kaler, J., and L. E. Green. 2013. Sheep farmer opinions on the current and future role of veterinarians in flock health management on sheep farms: A qualitative study. Prev. Vet. Med. 112:370-377.

Kelton, D., T. Von Konigslow, N. Perkins, A. Godkin, G. MacNaughton, and R. Cantin. 2014. Quantifying the cost of removing fecal shedders in a voluntary Johne's disease control program. Page 120 in Proc. 12th Int. Colloq. Paratuberculosis, Parma, Italy. International Association for Paratuberculosis.

Kleen, J. L., O. Atkinson, and J. P. T. M. Noordhuizen. 2011. Communication in production animal medicine: Modelling a complex interaction with the example of dairy herd health medicine. Ir. Vet. J. 64:8.

Klerkx, L., M. Schut, C. Leeuwis, and C. Kilelu. 2012. Advances in knowledge brokering in the agricultural sector: Towards innovation system facilitation. IDS Bull. 43:53-60.

Kovich, D. A., S. J. Wells, and K. Friendshuh. 2006. Evaluation of the Voluntary Johne's Disease Herd Status Program as a source of replacement cattle. J. Dairy Sci. 89:3466-3470.

Kreausukon, P., P. Gellert, S. Lippke, and R. Schwarzer. 2012. Planning and self-efficacy can increase fruit and vegetable consumption: A randomized controlled trial. J. Behav. Med. 35:443-451.

Krebs, P., J. O. Prochaska, and J. S. Rossi. 2010. A meta-analysis of computer-tailored interventions for health behavior change. Prev. Med. 51:214-221.

Kristensen, E., and C. Enevoldsen. 2008. A mixed method inquiry: How dairy farmers perceive the value(s) of their involvement in an intensive dairy herd health management program. Acta Vet. Scand. 50:50.

Kristensen, E., and E. B. Jakobsen. 2011a. Challenging the myth of the irrational dairy farmer: Understanding decision-making related to herd health. N. Z. Vet. J. 59:1-7.

Kristensen, E., and E. B. Jakobsen. 2011b. Danish dairy farmers' perception of biosecurity. Prev. Vet. Med. 99:122-129.

Kuiper, D., J. Jansen, R. J. Renes, C. Leeuwis, and H. G. Van der Zwaag. 2005. Social factors related to mastitis control practices: The role of dairy farmers' knowledge, attitude, values, behaviour and networks. Pages 576-582 in Proc. Mastitis in Dairy Production: Current Knowledge and Future Solutions. Proc. 4th IDF Intern. Mastitis Conf., Maastricht, the Netherlands. Wageningen Academic Publishers, Maastricht, the Netherlands.
Lam, T. J. G. M., J. Jansen, B. Van den Borne, and J. Van Veersen. 2007. A structural approach of udder health improvement via private practitioners: Ups and downs. Pages 142-151 in Proc. 46th Annu. Mtg. Natl. Mastitis Counc., San Antonio, TX. Natl. Mastitis Counc., Inc., New Prague, MN

Lam, T. J. G. M., J. Jansen, B. H. P. Van den Borne, R. J. Renes, and H. Hogeveen. 2011. What veterinarians need to know about communication to optimise their role as advisor on udder health in dairy herds. N. Z. Vet. J. 59:8-15.

Lam, T. J. G. M., J. Jansen, R. J. M. Van Gent, J. C. L. Van Veersen, J. M. Keurentjes, and A. G. Werkman. 2010. Directions for national mastitis control programs: Experiences from the Netherlands. Pages 142-146 in Mastitis Research into Practice: Proc. 5th IDF Mastitis Conf. J. E. Hillerton, ed.: Christchurch, New Zealand.

Lam, T. J. G. M., B. H. P. Van den Borne, J. Jansen, K. Huijps, J. C. L. van Veersen, G. van Schaik, and H. Hogeveen. 2013. Improving bovine udder health: A national mastitis control program in the Netherlands. J. Dairy Sci. 96:1301-1311.

Lanyon, S. R., M. L. Anderson, and M. P. Reichel. 2015. Survey of farmer knowledge and attitudes to endemic disease management in South Australia, with a focus on bovine viral diarrhoea (bovine pestivirus). Aust. Vet. J. 93:157-163.

Leach, K. A., H. R. Whay, C. M. Maggs, Z. E. Barker, E. S. Paul, A. K. Bell, and D. C. Main. 2010a. Working towards a reduction in cattle lameness: 1 . Understanding barriers to lameness control on dairy farms. Res. Vet. Sci. 89:311-317.

Leach, K. A., H. R. Whay, C. M. Maggs, Z. E. Barker, E. S. Paul, A. K. Bell, and D. C. Main. 2010b. Working towards a reduction in cattle lameness: 2. Understanding dairy farmers' motivations. Res. Vet. Sci. 89:318-323.

Lindahl, E., N. Sattorov, S. Boqvist, and U. Magnusson. 2015. A study of knowledge, attitudes and practices relating to brucellosis among small-scale dairy farmers in an urban and peri-urban area of Tajikistan. PLoS One 10:e0117318.

Lindberg, A., J. Brownlie, G. J. Gunn, H. Houe, V. Moenning, H. W. Saatkamp, T. Sandvik, and P. S. Valle. 2006. The control of bovine viral diarrhoea virus in Europe: Today and in the future. Rev. Sci. Tech. 25:961-979.

Mantler, T. 2013. A systematic review of smoking youths' perceptions of addiction and health risks associated with smoking: Utilizing the framework of the health belief model. Addict. Res. Theory 21:306-317.

Mee, J. F. 2007. The role of the veterinarian in bovine fertility management on modern dairy farms. Theriogenology 68(Suppl. 1):S257-S265.

Merkel, R. C., and T. A. Gipson. 2011. Change in behavior of goat producers after on-line training in herd health practices. Small Rumin. Res. 98:31-34.

Mill, J. M., and W. R. Ward. 1994. Lameness in dairy cows and farmers' knowledge, training and awareness. Vet. Rec. 134:162-164.

Moore, D. A., M. L. Merryman, M. L. Hartman, and D. J. Klingborg. 2008. Comparison of published recommendations regarding biosecurity practices for various production animal species and classes. J. Am. Vet. Med. Assoc. 233:249-256.

Nayga, R. M. J., R. Woodward, and W. Aiew. 2006. Willingness to pay for reduced risk of foodborne illness: A nonhypothetical field experiment. Can. J. Agric. Econ. 54:461-475.

Nielsen, S. S. 2011. Dairy farmers' reasons for participation in the Danish control programme on bovine paratuberculosis. Prev. Vet. Med. 98:279-283.

Noar, S. M., C. N. Benac, and M. S. Harris. 2007. Does tailoring matter? Meta-analytic review of tailored print health behavior change interventions. Psychol. Bull. 133:673-693.

Noordhuizen, J., J. C. da Silva, S. J. Boersema, and A. Vieira. 2008a. Veterinary advice to entrepreneur-like dairy farmers regarding quality risk management. Pages 219-247 in Applying HACCPBased Quality Risk Management on Dairy Farms. Wageningen Academic Publishers, Wageningen, the Netherlands.

Noordhuizen, J., J. C. da Silva, S. J. Boersema, and A. Vieira. 2008b. Communication in the veterinary advisory practice: Practical ap- 
plication of behavioural economics and communication skills. Pages 249-270 in Applying HACCP-Based Quality Risk Management on Dairy Farms. Wageningen Academic Publishers, Wageningen, the Netherlands.

Norton, S., C. Heuer, and R. Jackson. 2009. A questionnaire-based cross-sectional study of clinical Johne's disease on dairy farms in New Zealand. N. Z. Vet. J. 57:34-43.

OIE Animal Production Food Safety Working Group. 2006. Guide to good farming practices for animal production food safety. Rev. Sci. Tech. 25:823-836.

Öhlmér, B., K. Olson, and B. Brehmer. 1998. Understanding farmers' decision making processes and improving managerial assistance. Agric. Econ. 18:273-290.

Orji, R., J. Vassileva, and R. Mandryk. 2012. Towards an effective health interventions design: An extension of the health belief model. J. Public Health Inform. 4. https://doi.org/10.5210/ojphi. $\mathrm{v} 4 \mathrm{i} 3.4321$.

Østerås, O., and L. Sølverød. 2009. Norwegian mastitis control programme. Ir. Vet. J. 62(Suppl 4):S26-S33.

Parschau, L., L. Fleig, M. Koring, D. Lange, N. Knoll, R. Schwarzer, and S. Lippke. 2013. Positive experience, self-efficacy, and action control predict physical activity changes: A moderated mediation analysis. Br. J. Health Psychol. 18:395-406.

Peels, D. A., M. M. van Stralen, C. Bolman, R. H. Golsteijn, H. de Vries, A. N. Mudde, and L. Lechner. 2014. The differentiated effectiveness of a printed versus a Web-based tailored physical activity intervention among adults aged over 50. Health Educ. Res. 29:870-882.

Piepers, S., K. Lommelen, J. De Meulemeester, and S. De Vliegher 2011. 'DEMO project udder health': A first step towards a better udder health and milk quality in Flanders (Belgium). Pages 85-89 in Udder Health and Communication. H. Hogeveen and T. J. G. M. Lam, ed. Wageningen Academic Publishers, Wageningen, the Netherlands.

Pritchard, K., W. Wapenaar, and M. L. Brennan. 2015. Cattle veterinarians' awareness and understanding of biosecurity. Vet. Rec. 176:546.

Racicot, M., D. Venne, A. Durivage, and J. P. Vaillancourt. 2012a. Evaluation of strategies to enhance biosecurity compliance on poultry farms in Quebec: Effect of audits and cameras. Prev. Vet. Med. 103:208-218.

Racicot, M., D. Venne, A. Durivage, and J. P. Vaillancourt. 2012b. Evaluation of the relationship between personality traits, experience, education and biosecurity compliance on poultry farms in Quebec, Canada. Prev. Vet. Med. 103:201-207.

Raizman, E. A., S. J. Wells, S. M. Godden, J. Fetrow, K. Friendshuh, and J. Michael Oakes. 2006. Characterization of Minnesota dairy herds participating in a Johne's disease control program and evaluation of the program risk assessment tool. Prev. Vet. Med. $75: 22-33$.

Rehman, T., K. McKemey, C. M. Yates, R. J. Cooke, C. Garforth, R. B. Tranter, J. B. Park, and P. T. Dorward. 2007. Identifying and understanding factors influencing the uptake of new technologies on dairy farms in SW England using the theory of reasoned action. Agric. Syst. 94:281-293.

Relun, A., R. Guatteo, M. M. Auzanneau, and N. Bareille. 2013 Farmers' practices, motivators and barriers for adoption of treatments of digital dermatitis in dairy farms. Animal 7:1542-1550.

Reneau, J. K. 2001. Somatic cell counts: Measures of farm management and milk quality. Pages 29-37 in Proc. 40th Ann. Mtg. Natl. Mastitis Counc., Verona, WI. Natl. Mastitis Counc., Inc., New Prague, MN

Ritter, C., J. Jansen, K. Roth, J. P. Kastelic, C. L. Adams, and H. W. Barkema. 2016. Dairy farmers' perceptions towards the implementation of Johne's disease prevention and control strategies on Alberta dairy farms. J. Dairy Sci. 99:9114-9125.

Ritter, C., G. P. S. Kwong, R. Wolf, C. Pickel, M. Slomp, J. Flaig, S. Mason, C. L. Adams, D. F. Kelton, J. Jansen, J. De Buck, and H. W. Barkema. 2015. Factors associated with participation of Alberta dairy farmers in a voluntary, management-based Johne's disease control program. J. Dairy Sci. 98:7831-7845.
Roche, S. 2014. Investigating the role of agricultural extension in influencing Ontario dairy producer behaviour for Johne's disease control. PhD Thesis. University of Guelph, Ontario, Canada.

Roche, S. M., A. Jones-Bitton, M. Meehan, M. Von Massow, and D. F. Kelton. 2015. Evaluating the effect of Focus Farms on Ontario dairy producers' knowledge, attitudes, and behavior toward control of Johne's disease. J. Dairy Sci. 98:5222-5240.

Rodrigues, A. C. O., and P. L. Ruegg. 2005. Actions and outcomes of Wisconsin dairy farms completing milk quality teams. J. Dairy Sci. 88:2672-2680.

Russell, R. A., and J. M. Bewley. 2011. Producer assessment of dairy extension programming in Kentucky. J. Dairy Sci. 94:2637-2647.

Santman-Berends, I. M., M. Buddiger, A. J. Smolenaars, C. D. Steuten, C. A. Roos, A. J. Van Erp, and G. Van Schaik. 2014. A multidisciplinary approach to determine factors associated with calf rearing practices and calf mortality in dairy herds. Prev. Vet. Med. 117:375-387.

Sayers, R. G., M. Good, and G. P. Sayers. 2014. A survey of biosecurity-related practices, opinions and communications across dairy farm veterinarians and advisors. Vet. J. 200:261-269.

Sayers, R. G., G. P. Sayers, J. F. Mee, M. Good, M. L. Bermingham, J. Grant, and P. G. Dillon. 2013. Implementing biosecurity measures on dairy farms in Ireland. Vet. J. 197:259-267.

Schewe, R. L., J. Kayitsinga, G. A. Contreras, C. Odom, W. A. Coats, P. Durst, E. P. Hovingh, R. O. Martinez, R. Mobley, S. Moore, and R. J. Erskine. 2015. Herd management and social variables associated with bulk tank somatic cell count in dairy herds in the eastern United States. J. Dairy Sci. 98:7650-7665.

Scottish Monitor Farms Programme. 2014. Programme interim evaluation. Accessed Nov. 10, 2016. http://www.gov.scot/ Resource/0045/00457654.pdf.

Simon-Grifé, M., G. E. Martin-Valls, M. J. Vilar-Ares, I. Garcia-Bocanegra, M. Martin, E. Mateu, and J. Casal. 2013. Biosecurity practices in Spanish pig herds: Perceptions of farmers and veterinarians of the most important biosecurity measures. Prev. Vet. Med. 110:223-231.

Smiddy, M. P., R. O'Connell, and S. A. Creedon. 2015. Systematic qualitative literature review of health care workers' compliance with hand hygiene guidelines. Am. J. Infect. Control 43:269-274.

Solano, L., H. W. Barkema, C. Pickel, and K. Orsel. 2017. Effectiveness of a standardized footbath protocol for prevention of bovine digital dermatitis. J. Dairy Sci. 100:1295-1307.

Sorge, U., D. Kelton, K. Lissemore, A. Godkin, S. Hendrick, and S. Wells. 2010a. Attitudes of Canadian dairy farmers toward a voluntary Johne's disease control program. J. Dairy Sci. 93:1491-1499.

Sorge, U. S., J. Mount, D. F. Kelton, and A. Godkin. 2010b. Brief communication: Veterinarians' perspective on a voluntary Johne's disease prevention program in Ontario and western Canada. Can. Vet. J. 51:403-405.

Swinkels, J. M., A. Hilkens, V. Zoche-Golob, V. Kromker, M. Buddiger, J. Jansen, and T. J. Lam. 2015. Social influences on the duration of antibiotic treatment of clinical mastitis in dairy cows. J. Dairy Sci. 98:2369-2380.

Tiwari, A., J. A. Vanleeuwen, I. R. Dohoo, G. P. Keefe, J. P. Haddad, R. Tremblay, H. M. Scott, and T. Whiting. 2007. Production effects of pathogens causing bovine leukosis, bovine viral diarrhea paratuberculosis, and neosporosis. J. Dairy Sci. 90:659-669.

Toma, L., J. C. Low, B. Vosough Ahmadi, L. Matthews, and A. W. Stott. 2015. An analysis of cattle farmers' perceptions of drivers and barriers to on-farm control of Escherichia coli 0157. Epidemiol. Infect. 143:2355-2366.

Toma, L., A. W. Stott, C. Heffernan, S. Ringrose, and G. J. Gunn. 2013. Determinants of biosecurity behaviour of British cattle and sheep farmers: A behavioural economics analysis. Prev. Vet. Med. 108:321-333.

Tsui, L., S. A. Chapman, L. Schnirer, and S. Steweart. 2006. A handbook on knowledge sharing: strategies and recommendations for researchers, policymakers, and service providers. Accessed Nov. 12, 2016. https://uofa.ualberta.ca/-/media/ualberta / faculties-and-programs/centres-institutes/community-university- 
partnership/resources/publications/knowledgesharinghandbook. pdf.

Vaarst, M., T. B. Nissen, S. Østergaard, I. C. Klaas, T. W. Bennedsgaard, and J. Christensen. 2007. Danish stable schools for experimental common learning in groups of organic dairy farmers. J. Dairy Sci. 90:2543-2554.

Vaarst, M., and J. T. Sørensen. 2009. Danish dairy farmers' perceptions and attitudes related to calf-management in situations of high versus no calf mortality. Prev. Vet. Med. 89:128-133.

Vaillancourt, J. P., and D. K. Carver. 1998. Biosecurity: Perception is not reality. Poultry Digest 57:28-36.

Valeeva, N. I., T. J. G. M. Lam, and H. Hogeveen. 2007. Motivation of dairy farmers to improve mastitis management. J. Dairy Sci. 90:4466-4477.

Valeeva, N. I., M. A. van Asseldonk, and G. B. Backus. 2011. Perceived risk and strategy efficacy as motivators of risk management strategy adoption to prevent animal diseases in pig farming. Prev. Vet. Med. 102:284-295.

van Asseldonk, M. A. P. M., R. J. Renes, T. J. G. M. Lam, and H. Hogeveen. 2010. Awareness and perceived value of economic information in controlling somatic cell count. Vet. Rec. 166:263-267.

van den Borne, B. H., J. Jansen, T. J. Lam, and G. van Schaik. 2014 Associations between the decrease in bovine clinical mastitis and changes in dairy farmers' attitude, knowledge, and behavior in The Netherlands. Res. Vet. Sci. 97:226-229.

Vande Velde, F., E. Claerebout, V. Cauberghe, L. Hudders, H. Van Loo, J. Vercruysse, and J. Charlier. 2015. Diagnosis before treatment: Identifying dairy farmers' determinants for the adoption of sustainable practices in gastrointestinal nematode control. Vet. Parasitol. 212:308-317.

Wassink, G. J., L. J. Moore, R. Grogono-Thomas, and L. E. Green. 2005. Footrot and interdigital dermatitis in sheep: Farmers' practices, opinions and attitudes. Vet. Rec. 157:761-765.

Wauters, E., and C. Rojo Gimeno. 2014. Socio-psychological veterinary epidemiology. A new discipline for an old problem. Pages
133-151 in Proc. 32th Ann. Mtg. Soc. Vet. Epidemiol. Prev. Med. Dublin, Ireland. Soc. Vet. Epidemiol. Prev. Med.,

Weber, M. F., and T. J. G. M. Lam. 2012. Milk quality assurance programme for paratuberculosis results in increasing proportion of test-negative dairy herds. Page 305 in Proc. 13th International Symposium on Veterinary Epidemiology and Economics, Maastricht, the Netherlands.

Wells, S. J., and B. A. Wagner. 2000. Herd-level risk factors for infection with Mycobacterium paratuberculosis in US dairies and association between familiarity of the herd manager with the disease or prior diagnosis of the disease in that herd and use of preventive measures. J. Am. Vet. Med. Assoc. 216:1450-1457.

Wierup, M. 2012. Principles and strategies for the prevention and control of infectious diseases in livestock and wildlife. In Ecology and Animal Health. L. Norrgren and J. Levengood, ed. Baltic University Press, Uppsala, Sweden.

Wilson, L., A. P. Rhodes, and G. Dodunski. 2015. Parasite management extension-Challenging traditional practice through adoption of a systems approach. N. Z. Vet. J. 63:292-300.

Wolf, R., H. W. Barkema, J. De Buck, and K. Orsel. 2015. Factors affecting management changes on farms participating in a Johne's disease control program. J. Dairy Sci. 98:7784-7796.

Wolf, R., H. W. Barkema, J. De Buck, M. Slomp, J. Flaig, D. Haupstein, C. Pickel, and K. Orsel. 2014. High herd-level prevalence of Mycobacterium avium subspecies paratuberculosis in Western Canadian dairy farms, based on environmental sampling. J. Dairy Sci. 97:6250-6259.

Young, I., S. Hendrick, S. Parker, A. Rajic, J. T. McClure, J. Sanchez, and S. A. McEwen. 2010a. Knowledge and attitudes towards food safety among Canadian dairy producers. Prev. Vet. Med. 94:65-76.

Young, I., A. Rajic, S. Hendrick, S. Parker, J. Sanchez, J. T. McClure, and S. A. McEwen. 2010b. Attitudes towards the Canadian quality milk program and use of good production practices among Canadian dairy producers. Prev. Vet. Med. 94:43-53. 